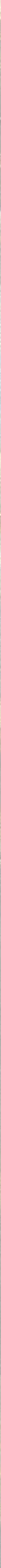




\section{The Thin Line Between Tradition and Transformation}

In 1621, the Twelve Years' Truce expired and Archduke Albert passed away. Remaining in Brussels as sole governess, Isabella now had to pursue those religious and political goals she had once shared with Albert. Soon after her husband's death, she ordered her court painter Peter Paul Rubens to design a monumental tapestry series depicting the Triumph of the Eucharist. Intended as a gift to the royal convent of Las Descalzas Reales in Madrid where she had in vain hoped to retire, the commission reflected her commitment, intertwining her personal devotion to the Eucharist with a powerful visualization of the Catholic Church's victory over Protestantism. In full baroque splendor, the centerpiece of the series depicts a personification of the Catholic Church, prominently holding up a Eucharistic monstrance and seated on a triumphal chariot, crushing incarnations of evil (fig. 151). ${ }^{1}$ The theme retained all its relevance in the 1620 , but this study of the role of religious material culture in the development of lay piety throughout the long sixteenth century demonstrates that the joint project of Rubens and the Infanta did not just emerge out of the blue. Just as Isabella was born in the midst of the troubles, on 12 August 1566, the roots for the Catholic re-establishment can be traced back to the middle of the sixteenth century. The classic perception of a waning medieval piety, as a linear decline accelerated by the introduction of Protestant thought around 1520 , reaching a dramatic climax in 1566 only to be restored by top-down archducal initiatives, has been demonstrated to be incorrect in several respects. This study's focus on the case of Zoutleeuw has contributed to challenging such generalizations and shown how a local perspective reveals an alternative story.

As I have argued throughout, a long-term approach allows for a more accurate assessment of the transformation of tradition that occurred during the period under study. As the previous pages have argued, that period was one marked by both continuity and change. But this raises the question of the meaning of these concepts: what

Figure 151, detail

Peter Paul Rubens, The triumph of the Church, c. 1625 , Madrid, Museo del Prado (C) MUSEO DEL PRADO is tradition, and what is innovation? In the historiography of piety

(C) RUBEN SUYKERBUYK, 2020 | DOI:10.1163/9789004433106_012

This is an open access chapter distributed under the terms of the CC BY-NC-ND 4.o license. 


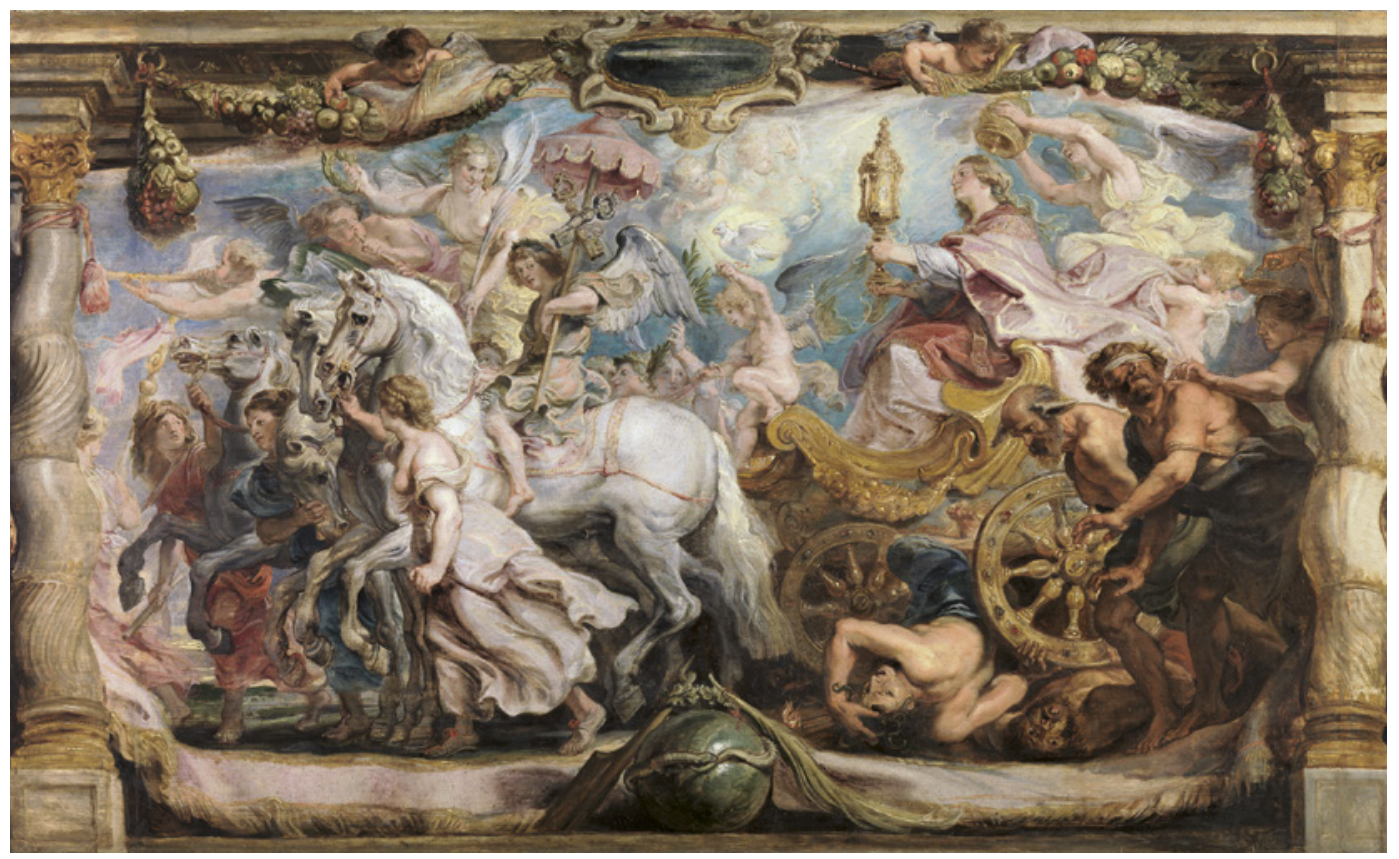

FIGURE 151

Peter Paul Rubens, The triumph of the Church, c. 1625, Madrid, Museo del Prado

(C) MUSEO DEL PRADO

in the Low Countries, ' 1520 ' is put forward as a decisive break with a long, medieval tradition. It should be clear that this, in part, corresponds to a widespread perception among contemporaries: the Utrecht cathedral chapter complained about Luther being one of the causes for its diminished income, and in 1526 Erasmus referred to the spreading of Protestant ideas as a 'new-fangled notion that pervades the whole world'. Only a few years before, however, in 1522, he had used a similar phrase, nova religio, to refer to something that is usually considered Protestantism's extreme opposite, namely a strikingly intense outward piety and accompanying excesses of pilgrimage. $^{2}$ As has been demonstrated (Chapter 2 ), such characterizations were typical of devotional life around 1500, in Zoutleeuw, the Low Countries and elsewhere in Europe. Still more strikingly, even Luther himself, the man who was held responsible for the dramatic changes of around 1520 , characterized the religious developments a few decades earlier as something incontestably new. He wrote acrimoniously about the 'new pilgrimages' (die newen walfarten) to places such as Wilsnack, Trier and Regensburg, and referred to the sudden popularity of the cult of Saint Anne as something that only originated when he was fifteen years old, i.e. around 1498. 'Before that', he maintained, 'nobody knew anything about her'. ${ }^{3}$ 
To a certain extent such typecasting was part of the respective confessional parties' broader strategy of denying each other's historical identity, and thereby also their legitimacy. Denouncing specific developments as mere novelties served to underscore the primacy of their own traditions. Similar mutual imputations occurred frequently in contemporaneous polemics. In a 1566 treatise that appeared immediately after the Beeldenstorm, Calvin was denounced as a liar for calling pilgrimages 'new inventions' (nieuwe inventien). ${ }^{4}$ And still in 1581, the Calvinist government of the city of Brussels tried to do away with Catholic miracle devotions by, among other things, proclaiming that the local cult of the Holy Sacrament of Miracle had only been instituted in $1529 .{ }^{5}$ While this claim can easily be proven wrong, this book has demonstrated the aptness of such observations: these examples demonstrate the intricate tensions between and relativity of 'old' and 'new', or 'tradition' and 'innovation', as historical categories, prompting closer reflection on the present use of such concepts to refer to developments in the past. One need not take recourse to the concept of invented traditions to account for the various confessional stances on this matter, since, after all, every 'genuine' tradition is a process.

This is most clearly demonstrated by the striking parallels between the two 'cultures of the miraculous' that have been identified around 1500 (Chapter 2) and 1600 (Chapter 8), respectively. In the first place, these reveal the vital, late medieval roots of Counter-Reformatory culture. The strength of this tradition of local pilgrimages proved crucial for the Catholic réveil of around 16oo. In this respect, the observations on Zoutleeuw and the Low Countries correspond to conclusions in other European studies. The indications are in line with Duffy's characterization of the tenacity of 'traditional religion' in England, and the reasons why temporary restoration under the reign of Mary Tudor (1553-1558) was possible. Soergel has similarly emphasized how the Counter-Reformation in Bavaria was essentially built on the fertile ground of late medieval shrines. Yet, while there are definitely pertinent similarities, the context had changed drastically. In the course of the intervening century, politico-religious developments had dramatically overturned the religious landscape and its geography. Local practices and occasional divergence notwithstanding, it is safe to say that, around 150o, religious life in Europe could still generally be characterized as part of one more or less uniform confession, i.e. the Church of Rome. The situation was completely different around 1600 , when religious 
identities and political factions had strongly polarized the confessional landscape, with far-reaching consequences for religious experience and practice. While studying the Counter-Reformation in the Upper Palatinate, Trevor Johnson similarly noticed the continuity with late medieval spirituality, but also emphasized that the tone of its main characteristics had changed. It was now much more militant and confessional.

Johnson's conclusions also apply to the Low Countries, where the advancing Reformation gradually aroused a parallel countermovement that cut across the principles of the various Protestant convictions (Chapter 6). In the mid-sixteenth century, elements that had been central to the Low Countries' devotional culture of around 1500 received a radically new dimension: Eucharistic devotion developed into a 'warlike confession of faith', and the practice of pilgrimage and the belief in miracles took on a strong confessional character (Chapters $4 \& 8$ ). ${ }^{6}$ Both were part of Catholic tradition, but their connotations in the period around 1500 differed radically from those around 16oo. The developments of the mid-sixteenth century should thus be seen as catalysts, paving the way for Early Modern Catholicism and its manifestation in archducal projects. Moreover, even if Albert and Isabella's reign can be said to epitomize the Catholic restoration in the Low Countries, they were, in fact, often responding to pre-existing revitalizing dynamics, and showing a marked interest in local devotions (Chapter 9). When they invested in the Brussels cult of the Holy Sacrament of Miracle to foreground it as spiritual weapon against Protestantism, they were clearly harking back to their predecessors' efforts during the previous century. Similarly, the iconography of the Triumph of the Eucharist Rubens designed for Isabella (fig. 151) matches seamlessly with that of the Dordrecht choir stalls of $1538-1540$ (fig. 115). And in spirit, it expresses the very same idea as the sacrament house Cornelis Floris installed in Zoutleeuw in the early 155os. Such examples demonstrate how Netherlandish devotional culture of around 1600 had, in a way, grown organically from late medieval piety, but was seasoned and shaped by the sixteenth-century tempest.

Examining religious material culture as primary sources reveals early initiatives to counter Protestant critiques, and contradicts Pollmann's claim that there was only a limited Catholic response to the Reformation in the Low Countries. While such actions are generally thought to have taken place only after 1585 - a view recently confirmed by Muller - in recent years the timeline has been 
altered considerably: Spicer and Jonckheere identified 1566 as a crucial catalyzing moment in this respect. But the observations in this book tend to confirm Tacke and Van Eck's hypotheses that Catholic reactions to Protestant ideas were already increasingly articulated in previous decades through visual and material statements. Well before the actual destructions in the Beeldenstorm of 1566 , religious objects had become involved in public debates: they were criticized by some, but their reinstallation, by others, in more monumental and elaborate forms, can be read as a strong response. With hindsight, these initiatives clearly were not successful in turning the tide, but an awareness of their existence and insight into their purposes considerably enrich our understanding of religious life and artistic production in the mid-sixteenth-century Low Countries, distinct from the mere implication of Tridentine decrees.

Also in a broader sense, this book puts further emphasis on the increasing importance of lay initiatives, participation and engagement in the religious developments of the Low Countries in the long sixteenth century, as has in recent years been put forward by scholars such as Van Engen, Terpstra, Marnef and Van Bruaene. In the consecutive dynamics that have been described, the crucial role of lay groups' agency indeed clearly was a recurring factor. To a significant extent, focus has been on the important local institution of the churchwardens in Zoutleeuw. Their initiatives were of prime importance for the establishment of the cult of Saint Leonard within a broader pilgrimage circuit (Chapter 1). In other places in the Low Countries, evidence indicates that similar initiatives were actively stimulated by local lords (Chapter 2). These local lay elites - lords as well as churchwardens - would also play a crucial role in attempts to counter the Reformation on the community level (Chapter 6). While some lent active support to the Reformation in one place, others committedly countered critiques elsewhere. Finally, churchwardens and the civic magistracy in Zoutleeuw were both found to be prime driving forces behind the revitalization of the local cult of Saint Leonard, after years of disastrous war (Chapter 8). To be clear, this emphasis on the laity is not intended to disregard the role of the clergy. But lay groups clearly responded to, and interacted with, pre-existing clerical structures, whether in the form of established pilgrimage circuits and centers, the indulgence system or the cult of the Holy Sacrament. While these are all aspects of religious life that had been made possible by clerical decisions, the laity clearly tried to take over parts of the organization or at least get involved in it. 
Religious material culture formed the core of this book, but the focus was not so much on the creative processes of artists or craftsmen as on their patrons as creators. As was also the case elsewhere, patrons in Zoutleeuw made reasoned choices within a multitude of possibilities that determined the final outlook of the objects in question. The carved wooden altarpiece depicting the life of Saint Leonard, for instance, was clearly an inherent part of a much broader campaign to embellish the sacred space of Saint Leonard's chapel. With the help of a broad range of artists, the churchwardens intentionally created an ensemble that foregrounded and enshrined Saint Leonard's statue as the material focus of the cult in Zoutleeuw. The sacrament house was similarly the product of choices on the part of its patrons, nobleman Merten van Wilre and his wife Marie Pylipert, and it was precisely such choices - form, size, style, iconographical motives - that conveyed deep meaning in the religious debates on the materiality of devotion. The eventual result served as a statement in favor of continuity. Finally, all the evidence suggests that by ordering the painting depicting the miracle of Paulus Gautier, the churchwardens deliberately linked with the relatively recent development of votive paintings to restore tradition. Patrons, like artists, made deliberate choices between tradition and innovation.

In sum, all this adds to our understanding of the multiple layers of meaning pilgrims and parishioners must have attached to Zoutleeuw's rich furnishings, visiting the church on the eve of the Beeldenstorm. The Marianum that welcomed entering devotees might have incited them to recite the prayer Ave sanctissima Maria mater dei, perhaps almost automatically as a devotional habit, or precisely, and very consciously, in order to obtain the years of indulgence that were connected to that very act. The pilgrims who had selected the shrine of Zoutleeuw from among the much larger cult circuit in the Low Countries walked on to Saint Leonard's chapel, where the multitude of burning candles, suspended crutches, waxen and metal legs and figurines, and other votive gifts such as harnesses, reassured them of the cult object's effectiveness. Many among them would in turn leave their own ex-voto, in gratitude for a received gift, or as a token of careful hope for salvation. This heterogeneous group of significant objects, together with the other items installed by the churchwardens in honor of Saint Leonard, all contributed to a sense of miraculous charisma in the sacred space. On the saint's feast day in early November this would have been greater still, as the Mass in the chapel included polyphonic singing and extra honoring lauds. 
Sacred souvenirs of all these devotional experiences were proposed by the stallholders in the church portal, either in the form of metal badges or paper pennants.

Finally, the above observations help to qualify Duffy's concept of 'traditional religion'. In 1566 a large part of the parishioners would have remembered the old gothic sacrament house being replaced by the current antique one, which can be called traditional in terms of function but definitely not in terms of style and size, nor in spatial impact. Together with the donor's memorial stone in front of it, it formed a meaningful ensemble. Moreover, during the Mass of the Holy Sacrament on Thursday mornings the microarchitectural structure was involved in a similarly significant and quintessentially Catholic ritual: the adoration and benediction of the Holy Sacrament with candlelight and laudatory polyphonic music, for which purpose the brand new Eucharistic monstrance was temporarily taken out of the sacrament house and placed on the altar. And leaving the church whilst walking along the side chapels with the triptychs from the Antwerp workshops of Pieter Aertsen and Frans Floris, parishioners must have equally been struck by the traditional devotional subjects they had known for so long, such as the seven sorrows of the Virgin, which were now rendered in the same avant-garde style. These combinations of 'old' and 'new' went beyond mere tradition, and within a climate of increasing Protestant critiques they merged into unmistakable Catholic statements on the matter of piety. 